\title{
Inter-community Relations Factor on the Empowerment of the Aisle Community in Makassar City: A Structural Equation Model
}

\author{
Sukri Palutturi ${ }^{1 *}$ (D), Lalu Muhammad Saleh ${ }^{2}$ D, Muhammad Rachmat ${ }^{3}$, Achmad Mawardi Shabir ${ }^{4}$, St. Rosmanely ${ }^{1}$, \\ Muhammad Rafli Aidillah ${ }^{5}$, Jalaluddin Abdul Malek ${ }^{6}$, Eun Woo Nam ${ }^{7}$ (D) \\ ${ }^{1}$ Department of Health Policy and Administration, Faculty of Public Health, Universitas Hasanuddin, Makassar, \\ Indonesia; ${ }^{2}$ Department of Occupational Health and Safety, Faculty of Public Health, Universitas Hasanuddin, Makassar, \\ Indonesia; ${ }^{3}$ Department of Health Promotion and Behavioral Sciences, Faculty of Public Health, Universitas Hasanuddin, \\ Makassar, Indonesia; ${ }^{4}$ Department of Public Health, Faculty of Public Health, Universitas Hasanuddin, Indonesia; ${ }^{5}$ Center for \\ Research and Journal Management, Faculty of Public Health, Universitas Muslim Indonesia, Makassar, Indonesia; ${ }^{6}$ Department \\ of Social, Development, and Environment Studies, University Kebangsaan Malaysia, Bangi, Malaysia; ${ }^{7}$ Department of Health \\ Administration, Head of Healthy City Research Center, Yonsei University, Seoul, South Korea
}

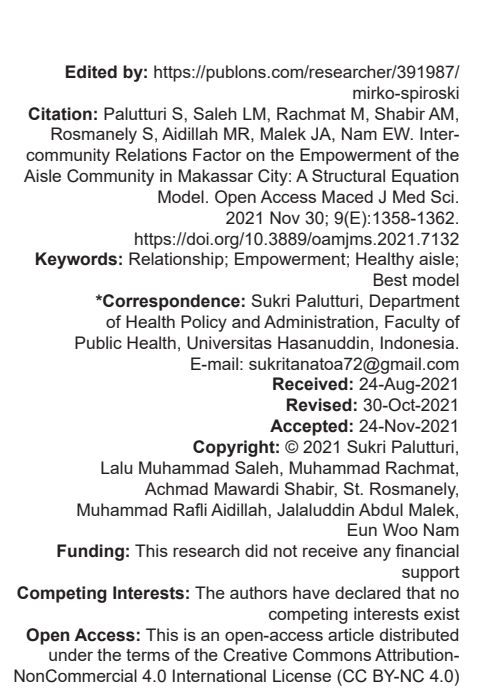

\section{Abstract}

BACKGROUND: There are several important factors in building community empowerment, one of them is the inter-community relationship. However, further research is rarely done on this dimension. The dimension of the relationship includes community structure, community strength, community motivation, community communication, community integrity, community participation, and community development.

AIM: This study aimed to find the best model in developing a healthy aisle in Makassar City.

METHODS: This research was conducted in two sub-districts in Makassar City, those are Rappocini District and Ujung Tanah District. The research samples involved were 560 households in Lorong. Data analysis was performed using multivariate analysis through the structural equation model test.

RESULTS: The results of this study found that clear vision $(C R=3.219$ and $p=0.01)$, capacity development $(C R=$ 3.166 and $p=0.02)$, norms existence $(C R=3.143$ and $p=0.02)$ on inter-community relationship significantly affected the aisle community empowerment. Availability of educational media $(C R=7.074$ and $p=0.00)$ significantly affected the condition of the healthy aisle in Makassar City.

CONCLUSION: Inter-community relationship is the best model in developing a healthy aisle in Makassar City through solidarity, shared motivation, shared trust, clear vision, resources shares, capacity building, norms in society, government support, and community development. This study recommends that in order to maximize a clear vision for the aisle community working group, the government should carry out legality regarding the aisle community structure.

\section{Introduction}

Healthy environmental sanitation is something that is difficult to find, especially in slum areas and dense urban settlements in Indonesia [1]. In general, the poor in Indonesia do not have access to basic sanitation or defecate in the open or in rivers and waterways [2]. Several dimensions of urban poverty can be seen in lowincome levels, poor health conditions, low education, vulnerability, slum dwellings, and powerlessness [3]. The responsibility of the community on the development is essential [4], [5]. These responsibilities include areas that are often marginalized, such as the aisle as a micro setting [6], [7], [8], in various aspects including healthy aisle [9]. The community has the power, ability, organization/institution, cooperation, intellectual ability, and commitment [10]. In addition, community also has good strength from the physical, material, economic aspects. One area of the city that is frequently neglected from the attention of the city government is the aisle. The term aisle is very strongly attached to Makassar City. By utilizing the healthy aisle community in Makassar City, it can encourage the improvement of the community economy. Therefore, when their economy is fulfilled, then the community can access all the facilities they want in the human development index (education, health, and economy) [11].

In the city of Makassar there are alley settlements in 14 sub-districts and alley settlements can be categorized as slums or not slums depending on the five aspects, namely environmental conditions, population conditions, building conditions, basic facilities, and infrastructure conditions, and socioeconomic conditions [12]. Slums or slums are 
settlements or housing for urban poor people who are densely populated, located on the sides of dirty roads or alleys, and are part of the city as a whole [13].

The main problem of this research is the condition of the aisle in Makassar, namely dirty, poor sanitation, crowded, narrow. In addition, the people who live in the Aisle are the most densely populated and the number of poor people is quite large, so that this area is prone to fire disasters but at the same time becomes an area that is prone to flooding every rainy season [14].

Healthy aisle in Makassar City is the creation of a healthy, comfortable, and clean aisle environment through community efforts [9]. This definition was developed from healthy regencies/cities in Indonesia [15], [16], [17], [18]. The aisle community empowerment which is oriented to economy, social, and health can be an effective strategy in responding to the current challenges. However, the empowerment of the aisle community also requires a special strategy in understanding the conditions and characteristics of the community. According to Palutturi et al. (2021), there are several considerations in community empowerment, those are inter-community relationships, community structure, community strength, community motivation, community communication, community integrity, community participation, and community development [9].

The focus of this study is the inter-community relationship in community empowerment with the purpose to find the best model for the effect of the intercommunity relationship on the condition of healthy aisle in Makassar City.

\section{Methods}

This research was conducted through a quantitative study. This research was conducted in 2 sub-districts in Makassar City, those are Rappocini Sub-District and Ujung Tanah Sub-District in 2020. The population was obtained from the number of families in the aisles. The total of aisle in the two sub-districts is 160 aisles. Among these aisles, there were 3494 family units. Thus, this research identified a total of 3494 families. Table 1 shows that there were 560 people who were the samples of this study spread over two subdistricts, namely, Ujung Tanah and Rappocini.

Tab1e 1: Distribution of respondents based on the Sub-District

\begin{tabular}{lll}
\hline Sub-District & $\mathrm{n}$ & Percentage \\
\hline Ujung Tanah & 199 & 36 \\
Rappocini & 361 & 64 \\
Total & 560 & 100 \\
\hline
\end{tabular}

Data were collected using a household questionnaire on 560 respondents which were tested and validated by the research team. The data collected includes government support, clear vision, capacity development, norms existence, feedback, resources, build trust, share resources, solidarity, capability equality, cleanliness, drainage, garbage transport, utilization of aisle, security system, no smoking area, integrated health post, availability of educational media, working group, and healthy aisle. Data are collected by enumerators who have received training from the research team to maintain the quality of data collection.

Data analysis was conducted using multivariate analysis with the structural equation model (SEM) test using the Statistical Package for Social Science and IBM Amos.

\section{Results}

Table 2 shows that the gender is female (51.8\%) then dominated by the respondent's occupation, namely housewives (60.7\%). Most of the respondents were adults between 20 and 60 years (87.7\%).

Table 2: Characteristics of respondents

\begin{tabular}{lll}
\hline Characteristics of respondents & $\mathrm{n}$ & $\%$ \\
\hline Sex & & \\
$\quad$ Male & 270 & 48.2 \\
$\quad$ Female & 290 & 51.8 \\
Age (Years) & & \\
$11-19$ & 24 & 4.3 \\
$20-60$ & 491 & 87.7 \\
$>60$ & 45 & 8.0 \\
Occupation & & \\
Government employees & 34 & 6.1 \\
Entrepreneur & 245 & 43.8 \\
Retired & 35 & 6.3 \\
Housewife & 177 & 31.6 \\
Not working & 69 & 12.3 \\
Total & 590 & 100 \\
\hline
\end{tabular}

In this case, the inter-community relationship refers to the community condition in the form of solidarity, shared motivation, shared trust, shared vision, resources shares, capacity building, and the existence of norms in society, government support, and community development. Some of these factors were tested in terms of whether they are able to build good healthy aisle conditions in a situation with a certain relationship level in the community.

\section{SEM}

Based on the model in Figure 1, the best model results found that there was a significant intercommunity relationship in empowering the aisle community toward a healthy aisle in Makassar City. The calculations are presented as Table 3.

Based on the results of the standardized estimate parameter presented in Table 3, it shows that the C.R. or critical ratio value indicates that the higher the value, the more significant it is. Based on these results, clear vision $(C R=3.219$ and $p=0.01)$ on inter-community relationships significantly affected the community empowerment, capacity development $(C R=3.166$ and 
$p=0.02$ ) on inter-community relationships significantly affected the community empowerment, and Norm existence $(C R=3.143$ and $p=0.02)$ on inter-community relationship significantly affected the empowerment of aisle community. In addition, the results presented in Table 2 also indicated that the availability of educational media (C.R. $=7.074$ and $p=0.00$ ) significantly affected the condition of the healthy aisle in Makassar City, and the use of aisle also significantly affected the healthy aisle conditions in Makassar City.

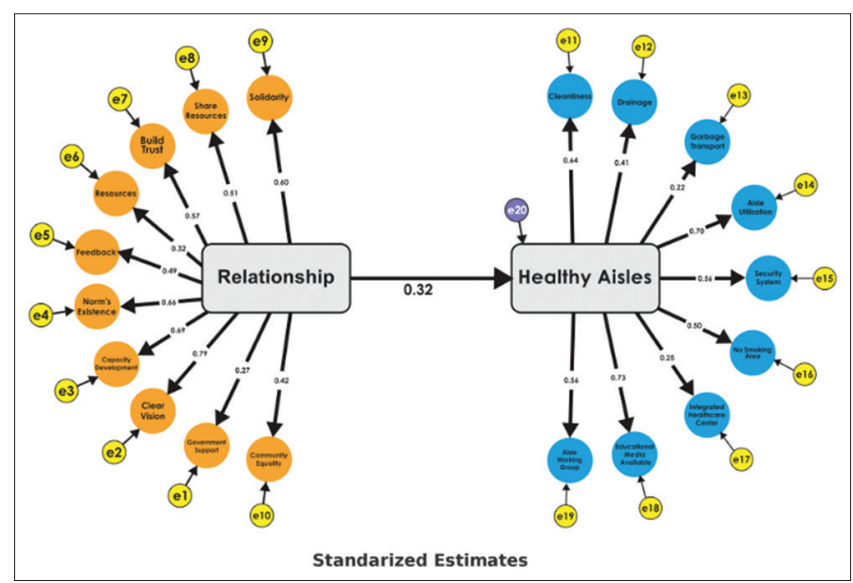

Figure 1: Structural Equation Model (SEM): Relationship in aisle community empowerment on healthy aisle in Makassar City

\section{Model accuracy index}

The structural equation model has several types of model fit. The most popular ones are CMIN, Goodness of Fit Index (GFI), Comparative Fit Index (CFI), and Root Mean Square Error of Approximation (RMSEA). The results of the determination of the factor relationship model in the empowerment of the aisle community are explained in Table 4.

The analysis results of kai-square value (CMIN) obtained $378.8(p>0.05)$, indicating that there was no significant difference between the data and model used. In the other words, the model we used has represented the data.
Based on Table 5 the Goodness of Fit Model Accuracy Index obtained was $0.794(<0.9)$, indicating that the data is included in the marginal fit group. The value of the CFI is also at a value of $(0.721<0.9)$ which means the data is included in the marginal fit group. Meanwhile, the RMSEA value of 0.097 which is above 0.08 is considered a good fit.

Based on Table 6, the results of the Akaike Information Criteria obtained was 456.8 (>10), thus it can be concluded that the standardized estimate model (a) Relationship in the empowerment of Aisle Community in Makassar City has fulfilled the description.

\section{Discussion}

The results showed that if the inter-community relationship has a clear vision in the efforts of community empowerment, then it will have a significant impact. In addition, such a clear vision also affected the achievements achieved, so that it can be directed and measured. In this case, sustainable community empowerment activities are clear visions for the future [19], [20]. A clear vision requires encouragement/ support from the local government and the private sector so that the community has a vision that is directed towards future regional planning [21]. Community empowerment challenges that involve all elements of society in addition to providing a clear vision in this regard must offer community capacity-building. This capacity-building aimed to increase the rationality and the understanding of the community in terms of education concerning the vision design [22].

Another challenge encountered in community empowerment is the existence of social norms that can be an obstacle but also can be a strength or distinctive characteristic in the empowerment of the aisle community. The community's tendency of thinking conventionally due to their lack of knowledge forces

Table 3: Regression weight standardized effect of the effect of the relationship in aisle communities empowerment on healthy aisle in Makassar city

\begin{tabular}{|c|c|c|c|c|c|c|}
\hline Parameter & Variable & Estimation & S.E. & C.R. & $\mathrm{p}$ & Label \\
\hline Healthy Aisles & Relationship & 0.730 & 0.312 & 2.340 & 0.019 & \\
\hline Government support & Relationship & 1.000 & & & & \\
\hline Clear vision & Relationship & 1.883 & 0.585 & 3.219 & 0.001 & \\
\hline Capacity Development & Relationship & 1.324 & 0.418 & 3.166 & 0.002 & \\
\hline Norms Existence & Relationship & 1.325 & 0.422 & 3.143 & 0.002 & \\
\hline Feedback & Relationship & 1.100 & 0.373 & 2.952 & 0.003 & \\
\hline Resources & Relationship & 0.968 & 0.383 & 2.529 & 0.011 & \\
\hline Build trust & Relationship & 1.162 & 0.379 & 3.061 & 0.002 & \\
\hline Share resources & Relationship & 0.908 & 0.305 & 2.976 & 0.003 & \\
\hline Solidarity & Relationship & 1.333 & 0.432 & 3.086 & 0.002 & \\
\hline Capability equality & Relationship & 0.958 & 0.340 & 2.818 & 0.005 & \\
\hline Cleanliness & Healthy Aisle & 1.000 & & & & \\
\hline Drainage & Healthy Aisle & 0.418 & 0.095 & 4.396 & *** & \\
\hline Garbage Transport & Healthy Aisle & 0.234 & 0.096 & 2.429 & 0.015 & \\
\hline Utilization of Aisle & Healthy Aisle & 1.134 & 0.165 & 6.884 & $* * *$ & \\
\hline Security system & Healthy Aisle & 0.916 & 0.158 & 5.812 & *** & \\
\hline No smoking area & Healthy Aisle & 0.822 & 0.157 & 5.240 & $* \star \star$ & \\
\hline Integrated Health Post & Healthy Aisle & 0.345 & 0.125 & 2.769 & 0.006 & \\
\hline $\begin{array}{l}\text { Availability of Educational } \\
\text { media }\end{array}$ & Healthy Aisle & 1.599 & 0.226 & 7.074 & $* * *$ & \\
\hline Working Group & Healthy Aisle & 1.180 & 0.204 & 5.778 & $\star \star \star *$ & \\
\hline
\end{tabular}


them to maintain norms that actually become an obstacle to their development. This can be overcome through a consistent approach and other efforts that can be made to share knowledge/experience through socialization and training so that it can increase the public awareness [23]. The management of the Healthy Aisle program in Makassar City has limited Human Resources but the budget is sufficient [24].

Table 4: Kai-square model accuracy index (CMIN) of relationship factor in aisle community empowerment in Makassar city

\begin{tabular}{llllll}
\hline Model & NPAR & CMIN & DF & P & CMIN/DF \\
\hline Default model & 39 & 378.844 & 151 & 0.000 & 2.509 \\
Saturated model & 190 & 0.000 & 0 & & \\
Independence model & 19 & 986.947 & 171 & 0.000 & 5.772 \\
\hline
\end{tabular}

Therearethreekeyfactorsthatcanbeconsidered in community empowerment, namely joint strategy, shared resources, and shared accountability [25]. Hence, it can be concluded that the activities of the alley community who seek to find common strengths in achieving the goals of empowerment are a major influence in establishing sustainable empowerment. Actually changing society is something that is difficult to do so the right strategy to form a conscious society is to develop community capacity, instill understanding in the community and make people consciously empower themselves and their environment [26]. The existence of norms and good relations in the community is a similarity that is upheld in the community, thanks to the similarity, the sense of mutual respect, please help is very high, then through the similarity of these entities community empowerment will be dynamic [22], [27].

Table 5: Model fit index of GFI, CFI, and RMSEA of relationship factor in aisle community empowerment in Makassar city

\begin{tabular}{lllllll}
\hline Model & CFI & RMR & GFI & AGFI & RMSEA & PGFI \\
\hline Default model & 0.721 & 0.024 & 0.794 & 0.741 & 0.097 & 0.631 \\
Saturated model & 1.000 & 0.000 & 1.000 & & & \\
Independence model & 0.000 & 0.066 & 0.499 & 0.444 & 0.173 & 0.449
\end{tabular}

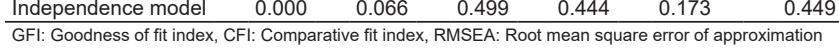
To solve this problem, the community's capacity needs to be improved through various trainings and community assistance, as well as a healthy hallway institution is very much needed to ensure the sustainability and management of the program in the future. For resource management in this study, in addition to the involvement of the research team, it was also assisted by representations in the alley community.

Table 6: AIC of relationship factor in the aisle community empowerment in Makassar city

\begin{tabular}{lllll}
\hline Model & AIC & BCC & BIC & CAIC \\
\hline Default model & 456.844 & 468.067 & 576.775 & 615.775 \\
Saturated model & 380.000 & 434.676 & 964.283 & 1154.283 \\
Independence model & 1024.947 & 1030.414 & 1083.375 & 1102.375 \\
\hline AIC: Akaike information criterion & & & &
\end{tabular}

\section{Conclusion}

Inter-community relationship is the best model in developing a healthy aisle in Makassar City through solidarity, shared motivation, shared trust, clear vision, resources shares, capacity building, norms in society, government support, and community development. It is clear that in the development of aisle community in Makassar City has a dominant effect as the basis for empowering the aisle community. It is suggested that in the efforts to improve human development, especially for the aisle community in Makassar City, the utilization of aisle components need to be considered by providing legality to the aisle working group so that the aisle community has a clear vision to orient healthy aisle into more complex aisle in overcoming urban problems.

\section{References}

1. Surtiani EE. Faktor-Faktor Yang Mempengaruhi Terciptanya Kawasan Permukiman Kumuh Di Kawasan Pusat Kota (Studi Kasus: Kawasan Pancuran, Salatiga), Thesis, Semarang: Universitas Diponegoro; 2006

2. Adhi ET. Pelayanan sanitasi buruk: Akar dari kemiskinan. J Ana Sos. 2009;14(2):76-87.

3. Yandri P, Juanda B. Memahami karakter kemiskinan perkotaan dengan pendekatan observasional. J Ekon Stud Pembang. 2018;19(1):75-84. http://doi.org/10.18196/jesp.19.1.4276.

4. Ismail M. Corporate social responsibility and its role in community development: An international perspective. J Int Soc Res. 2009;2(9):199-209.

5. Todd S, Drolet JL. Introduction: Community Practice and Social Development in Social Work. Todd WS, Drolet JL, editors. Dalam Community Practice and Social Development in Social. Singapore: Springer; 2020. p. 3-16. http://doi. org/10.1007/978-981-13-6969-8_23.

6. Fitry IN, Palutturi S, Thaha RM, Syam A. Impact evaluation of healthy city implementation in Makassar city. Open Access Maced J Med Sci. 2020;8:12-5.

7. Palutturi S, Asnawi A. Healthy city awards in South Sulawesi, Indonesia: Expectation and Challenges. J Health Transl Med. 2020;23:163-9.

8. Palutturi S, Chu C, Moon JY, Nam EW. A comparative study on healthy city capacity mapping: Indonesia and Korea. Soc Sci. 2015;10(6):848-54

9. Palutturi S, Saleh LM, Rachmat M, Malek JA. Mapping healthy aisles in Makassar city, Indonesia: Implications for community empowerment. Gac Sanit. 2021;35:S42-5. http://doi. org/10.1016/j.gaceta.2020.12.012 PMid:33832624

10. Widjajanti K. Model pemberdayaan masyarakat. J Ekon Pembang Kaji Masal Ekon Dan Pembang. 2011;12(1):1. https:// doi.org/10.23917/jep.v12i1.202

11. Daraba D, Akib H, Saggaf MS, Cahaya A, Salam R. Basic public service partnership model based on gender perspective in Makassar city, Indonesia. J Leg Ethical Regul Issues. 2018;21(4):1-12.

12. Jamala N, Latief MS, Amin S. Desain Lorong Pada Lingkungan Permukiman Di Kota Makassar. Makassar: Universitas Hasanuddin; 2015.

13. Supriyatno B. The attitude and role of Bekasi City government in slum areas. J Hum Behav Soc Environ. 2020;30(2):228-42. http://doi.org/10.1080/10911359.2019.1676359

14. Hamid H. Manajemen Pemberdayaan Masyarakat. Makassar: De La Macca; 2011. 
15. Palutturi S. Healthy Cities Implementation in Indonesia: Challenges and Determinants of Successful Partnership Development at Local Government Level. Australia: Thesis, Griffith University; 2013. http://doi.org/10.25904/1912/52

16. Palutturi S. Healthy Cities: Global Concepts, Local Implementation for Indonesia. Yogyakarta: Pustaka Pelajar; 2018.

17. Palutturi S, Darmawansyah, Nurhayani. Achievement and typology of partnership in implementation of healthy cities in Indonesia: A case study of Makassar. Int J Bus Econ Res. 2016;14(2):939-49.

18. Palutturi S, Rutherford S, Davey P, Chu C. Comparison between healthy cities and Adipura in Indonesia. Malays $\mathrm{J}$ Med Health Sci. 2013;9(1):35-43.

19. Sithole T, Mahlangu G, Salek S, Walker S. Evaluating the success of ZaZiBoNa, the Southern African development community collaborative medicines registration initiative. Ther Innov Regul Sci. 2020;54(6):1319-29. http://doi.org/10.1007/ s43441-020-00154-y

20. South J, Button D, Quick A, Bagnall AM, Trigwell J, Woodward J, et al. Complexity and community context: Learning from the evaluation design of a national community empowerment programme. Int J Environ Res Public Health. 2020;17(1):1. http://doi.org/10.3390/ijerph17010091

PMid:31877710

21. Aidillah MR, Palutturi S, Masni, Darmawansyah, Indar,
Salmah AU. The impact of effectiveness and participation in good governance on the quality of healthy urban planning in Makassar City, Indonesia. Eur J Biosci. 2020;14(2):6207-11.

22. Eger C, Miller G, Scarles C. Gender and capacity building: A multilayered study of empowerment. World Dev. 2018;106:207-19. http://doi.org/10.1016/j.worlddev.2018.01.024

23. Cislaghi B, Denny EK, Cissé M, Gueye P, Shrestha B, Shrestha PN, Ferguson G, et al. Changing social norms: The importance of 'organized diffusion' for scaling up community health promotion and women empowerment interventions. Prev Sci. 2019;20(6):936-46. http://doi.org/10.1007/ s11121-019-00998-3

24. Amran AR, Palutturi S, Nurhayani N. Analisis sistem manajemen program lorong sehat di Kota Makassar. Hasanuddin J Public Health. 2020;1(1):22-8. http://doi.org/10.30597/hjph.v1i1.9508

25. Elliott $I$, Fejszes $V$, Tàrrega $M$. The community empowerment act and localism under devolution in Scotland: The perspective of multiple stakeholders in a council ward. Int J Public Sect Manag. 2019;32(3):302-19. http://doi.org/10.1108/ IJPSM-03-2018-0080.

26. Kasmel A, Andersen PT. Measurement of community empowerment in three community programs in Rapla (Estonia). Int J Environ Res Public Health. 2011;8(3):799-817.

27. Entah AR. Community empowerment and conservation of Adat Nusantara Indonesia. J Law Policy Glob. 2017;68:49-58. 